\title{
The Roles and Impacts of Greenery Club in Kolej Tuanku Canselor Universiti Teknologi Malaysia
}

\author{
Joyce Sin Yin Sia, Matthias Foh Thye Tiong, Mu Wen Chuan, Muhammad Afiq
}

Abdul Aziz, Md. Fabilah Mat Esa, Amirjan Nawabjan, Roslan Abd. Ghani, Abdullah

Sani Ahmad, Sharul Kamal Abdul Rahim*

${ }^{1}$ Kolej Tuanku Canselor, Universiti Teknologi Malaysia, Skudai 81310, Malaysia.

*Corresponding author. Email: sharulkamal@utm.my

\begin{abstract}
Recently, interest in volunteerism focused on environmental sustainability has grown dramatically due to the alarming environmental issues such as global warming, foreign waste and greenhouse gases effects. A greenery club, namely Kelab Bumi Hijau (KBH) which consists of volunteering students led by Majlis Felow Kolej Tuanku Canselor (MFKTC), Universiti Teknologi Malaysia (UTM) has been set up in 2017 to monitor and improve the greenery particularly within Kolej Tuanku Canselor (KTC). Several activities have been carried out by KBH such as picking up litter, clearing unwanted shrubs and planting trees. This study is carried out to evaluate the relevance of KBH to the greenery of KTC. In addition, the challenges faced by $\mathrm{KBH}$ and their future plans are also highlighted. The results show that the greenery club namely KBH has not only enhanced the greenery and environment of KTC, but also cultivated volunteerism among the students. Although the data presented apply only to KTC, we believe that the volunteerism to sustain the greenery should be carried out in all residential college in UTM.
\end{abstract}

Keywords: greenery club; environment sustainability; volunteerism; global warming

\section{INTRODUCTION}

Environmental issues have become one of serious challenges face by humanity. Human activities such as open burning, deforestation, industrialization and plastic throwaways are destroying our environment and threatening the lives of future generations. It is notable that the environment is changing.

According to Surface Temperature Analysis conducted by Goddard Institute for Space Studies (GISS), the global warming magnitude has reached about $0.8{ }^{\circ} \mathrm{C}$ in 2010 , which is double compared to magnitude reported in 1981 (Lenssen et al., 2019; Team, 2019). It is believed that the average global temperature of Earth will keep rising and reach a new record of highest global temperature in every decade. Figure 1 shows the record of maximum, minimum and average temperature in Kuala Lumpur, Malaysia from year 2009 until today which adapted from World Weather Online. The maximum temperature has increased by $5{ }^{\circ} \mathrm{C}$, from $30{ }^{\circ} \mathrm{C}$ to $35^{\circ} \mathrm{C}$.

Beside global warming, waste disposal is also another environmental problem. Electronic wastes, plastics, etc could bring hazards and pollution to our environment. However, Malaysia has not been seen as a perfect country when it comes to waste management and cleanliness. Malaysia was ranked as 75th country Environmental Performance Index (EPI) in year 2018 (Wendling, 2018). On the other hand, Japan which is one of the cleanest countries where the Japanese have established culture of keeping everything clean. Trash cannot be found in any public area in Japan which is one thing that we should emulate.

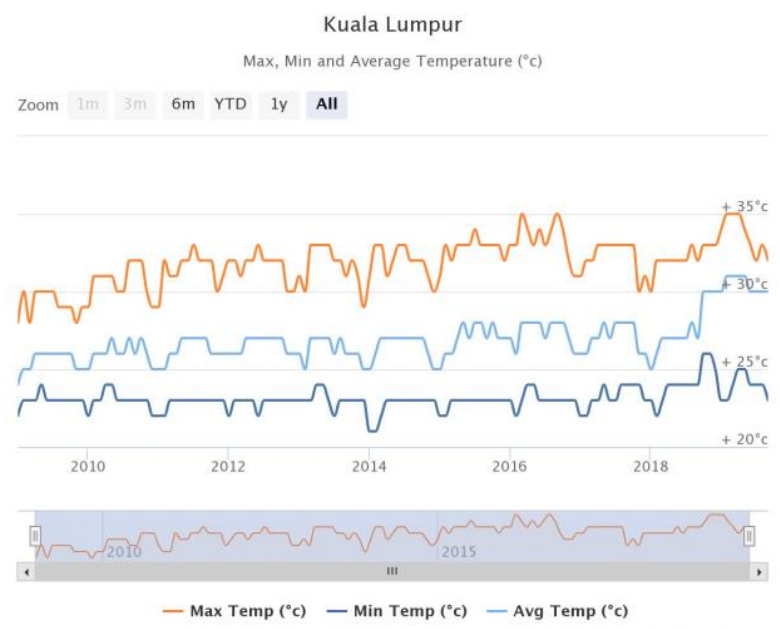

Figure 1 Maximum, minimum and average temperature in Kuala Lumpur, Malaysia [4]. 
Table 1 Overview of online questionnaire.

\begin{tabular}{|c|c|c|}
\hline No. & Questions & Possible Answers \\
\hline Q1 & $\begin{array}{l}\text { Are you aware of environmental issues? (global warming, animal } \\
\text { extinction, pollution and etc.) }\end{array}$ & Yes/ No \\
\hline Q2 & $\begin{array}{l}\text { Among all the activities held by the club, which activity do you } \\
\text { think has more impact to the environmental sustainability? }\end{array}$ & $\begin{array}{l}\text { Clearing unwanted shrubs/ } \\
\text { Picking up rubbish/ Planting } \\
\text { trees }\end{array}$ \\
\hline Q3 & Do you think KBH contribute on environmental sustainability? & Yes/ No \\
\hline Q4 & $\begin{array}{l}\text { Do you think the club did the great job to make KTC a better place } \\
\text { to live? }\end{array}$ & Yes/ No \\
\hline Q5 & Do you find volunteering in $\mathrm{KBH}$ activities interesting? & Yes/ No \\
\hline Q6 & Would you like to join the future activities organized by KBH? & Yes/ No \\
\hline Q7 & $\begin{array}{l}\text { Is collecting merit points your main target to participate in the } \\
\mathrm{KBH} \text { activities? }\end{array}$ & Yes/ No \\
\hline Q8 & Do you face any difficulties during the activities? & No option is available \\
\hline Q9 & Do you have any recommendations for future activities? & No option is available \\
\hline
\end{tabular}

To solve environmental issues, it starts with environmental awareness and volunteering hearts on the individual levels. Therefore, a greenery club, namely Kelab Bumi Hijau (KBH) has been set up in year 2017 by Majlis Felow Kolej Tuanku Chanselor (MFKTC), Universiti Teknologi Malaysia (UTM) as an initiation toward environment sustainability. The club consists of volunteering students and lead by MFKTC to monitor and improve the greenery particularly within KTC. Up until today, several activities have been carried out by KBH such as picking up litter, clearing unwanted shrubs and planting trees. The focus of this study is to evaluate the relevance of $\mathrm{KBH}$ to the greenery of KTC, the challenges faced by $\mathrm{KBH}$ and their future plans.

future research.

\section{LITERATURE REVIEW}

Volunteering in environment may bring positive influence on people toward pro-environment behaviors over time[5, 6]. A case study [7] has been made on participants of two volunteering programs, namely Green Gyms ${ }^{\circledR}$ and Action Teams organized by The Conservation Volunteers (TCV) in UK. Green Gyms ${ }^{\circledR}$ focuses on biodiversity and organic food growing while Action Teams is managing and conserving the natural habitats. Those volunteers exhibit overall improved impact across all of the proenvironmental behaviors except waste management. The authors address few reasons, including personal finance, time availability and current infrastructure-supporting which are the potential challenges for individuals to involve in environmental volunteering nowadays.

Another study has been conducted about the motivation behind Austria and Great Britain environmental volunteers. There are eight main motivation factors detected, which are "helping environment", "career", "user", "learning", "social", "project organization", "values and esteem", and "health and well-being" [8]. The highest response of the motivator from the study is to help the environment, which shows that there is a high environmental awareness in these two countries.

On the other hand, environment volunteering may also be integrated into the core part of tertiary students' course to encourage environmental volunteering, for example, in Edith Cowan University. In 2013, a research is conducted to evaluate the effectiveness of introducing community engagement and Workplace Integrated Learning (WIL) to their students. First year natural Sciences students were required to complete five days environmental work with community groups. In general, most of students give feedback that the experience is very useful in improving their job prospects upon graduation [9].

\section{METHODOLOGY}

This quantitative research was carried out within KTC. A total of 20 students have completed the online questionnaire. No face-to-face interview was carried out to keep the confidentiality of the respondents' personal identity. All the volunteers are UTM students who have 
previously participated in activities organized by $\mathrm{KBH}$ from the years 2017 to 2019 . The overview of the online questionnaire is tabulated in Table 1.

The questionnaire was designed to evaluate the importance of $\mathrm{KBH}$ towards the environment of KTC and the satisfactory levels of the participants. Most of the questions (Qs) come with bullet point options for answers to aid the respondents to answer the questionnaire. Q8 and Q9 were outlined to receive opinions and suggestions from the participants (if there is any as they are not compulsory questions). Moreover, Q7 was used as an evaluation to assess the volunteerism among the participants and to see whether merit points reward system is important to attract students to participate in activities involving greenery.

\section{RESULTS AND DISCUSSIONS}

Among the 20 respondents, there are 11 junior students (in their first and second year of study) and nine senior students (in their third and fourth year of study) as shown in Figure 2. From the respondents' responses to Q1, it was found that all the students are aware of the environmental issues such as global warming, animal extinction, pollution and other issues.

Figure 3 depicts the respondents' responses to Q2. Among the activities organized by $\mathrm{KBH}$, majority of the students have suggested that planting trees could bring more impact to the environmental sustainability. This is reasonable because green plants improve the greenery of the environment and produce oxygen during the day. The respondents' responses to Yes/No questions (Q3-Q7) are plotted in the same bar chart as shown in Figure 4. All students think that $\mathrm{KBH}$ is important for the environmental sustainability. Most of the students suggest that $\mathrm{KBH}$ has done a great job to make KTC a better place to live in terms of the improvements on greenery environment and the cleanliness of the residential colleges.

From Figure 4, it is also shown that only one student dislikes the activities organized by $\mathrm{KBH}$. Most of the students enjoy joining the greenery activities. In addition, by referring to the responses to Q6, majority of the students are willing to participate in the future greenery activities by $\mathrm{KBH}$ club. From Q7, 50\% of the students participate in the greenery activities to gain merit points. This indicates that proper documentation should be done to record list of participants. The record be systematically organized to sustain the number of participants in the future activities. This shows that merit reward is one of the important motivations for students.

From the questionnaire, a few students face difficulties with the time when the activities were held. They have suggested that the activities should be held with more variety of time slots. On the other hand, a few students think that the activities should be advertised and attract more participants because the greenery activities require a lot of manpower. Besides, there is a suggestion to organize reduce, reuse and recycle (3R) campaigns to raise awareness regarding environmental issues.

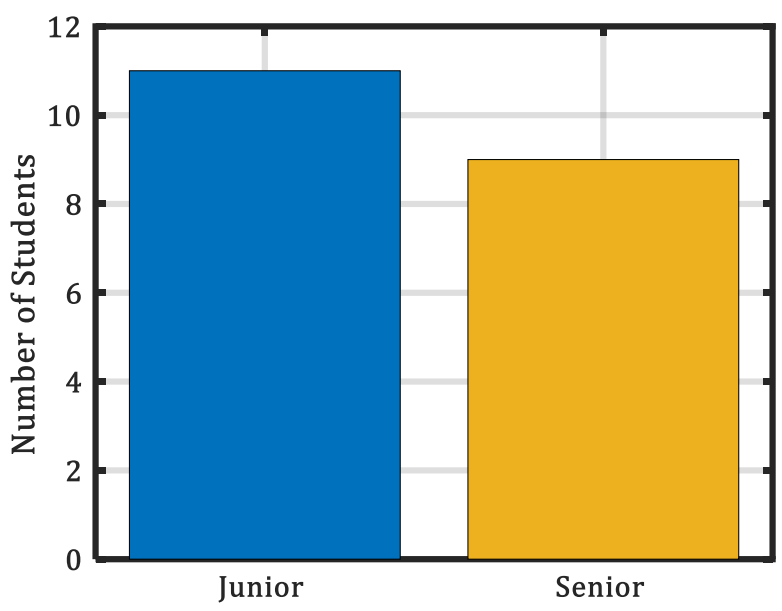

Figure 2 Categories of students.

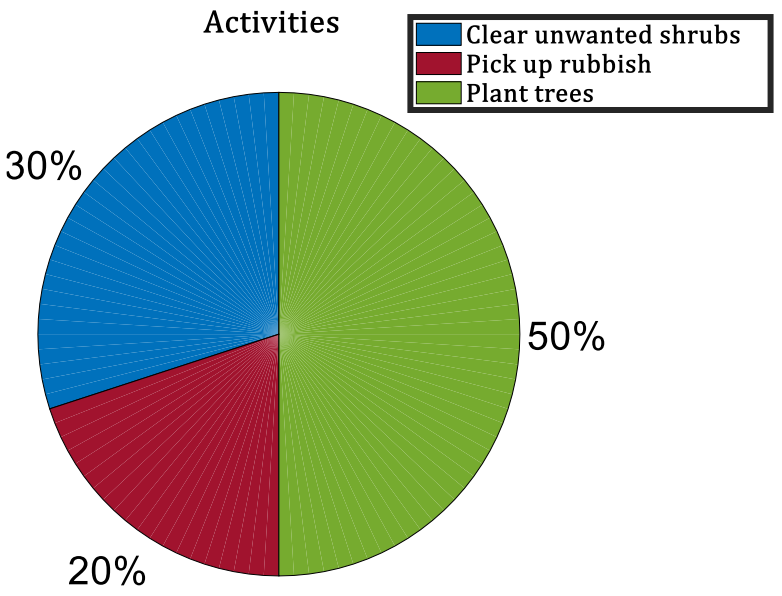

Figure 3 Responses to Q2.

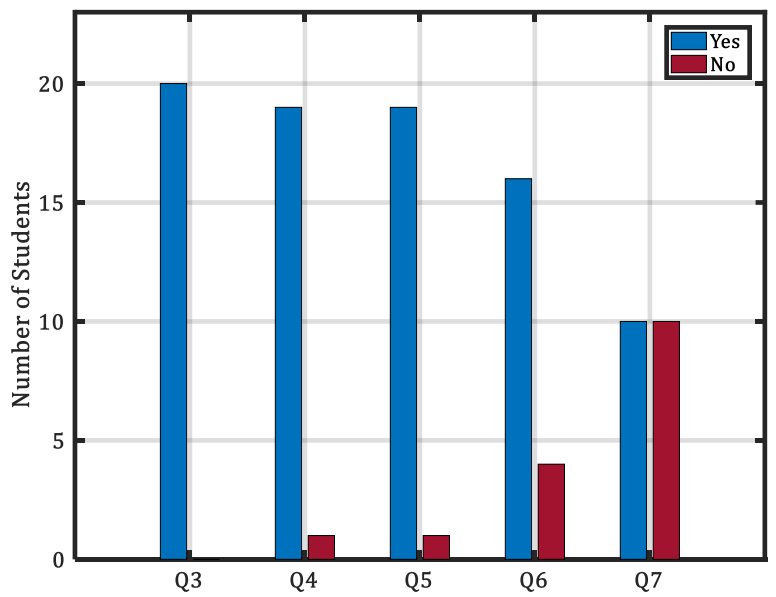

Figure 4 Responses to 'Yes/No' questions (Q3-Q7). 


\section{CONCLUSION}

Counting from year 2017 to 2019, number of students from KTC residences mushroomed to volunteer themselves actively in the activities that held by $\mathrm{KBH}$, for instances clear up unwanted shrubs, pick up rubbish and plant tree. Among the three activities, most of the participants agree that planting trees bring the most significant impact towards the environmental sustainability. Moreover, the students show their appreciation towards $\mathrm{KBH}$ for providing a good platform to cultivate their volunteerism and love towards their mother nature while most of them are looking forward to join the other coming activities. $\mathrm{KBH}$ has shown a good move to inspire the students living in KTC to take the responsibility on protecting the environment, which most people have forgotten. A larger success could be expected if $\mathrm{KBH}$ could attract more students to join their activities and plan for more well-scheduled activities, for instances more available time options.

\section{ACKNOWLEDGEMENT}

The authors would like to acknowledge the financial support from Kolej Tuanku Canselor, UTM. The authors also appreciate the time spent by the students who have taken part in the survey.

\section{REFERENCES}

[1] G. Team. GISS Surface Temperature Analysis (GISTEMP), version 4 [Online]. Available: https://data.giss.nasa.gov/gistemp/.

[2] N. J. L. Lenssen et al., "Improvements in the GISTEMP Uncertainty Model," Journal of Geophysical Research: Atmospheres, Article vol. 124, no. 12, pp. 6307-6326, 2019.

[3] Z. A. Wendling, Emerson, J. W., Esty, D. C., Levy, M. A., de Sherbinin, A., et al., "2018 Environmental Performance Index," New Haven, CT: Yale Center for Environmental Law \& Policy, 2018.

[4] W. W. Online. Kuala Lumpur Monthly Climate Averages [Online]. Available: https://www.worldweatheronline.com/kuala-lumpurweather-averages/kuala-lumpur/my.aspx

[5] C. Cooper, L. Larson, A. Dayer, R. Stedman, and D. Decker, "Are wildlife recreationists conservationists? Linking hunting, birdwatching, and pro-environmental behavior," Journal of Wildlife Management, Article vol. 79, no. 3, pp. 446-457, 2015.
[6] M. Dresner, C. Handelman, S. Braun, and G. Rollwagen-Bollens, "Environmental identity, proenvironmental behaviors, and civic engagement of volunteer stewards in Portland area parks,"

Environmental Education Research, Article vol. 21, no. 7, pp. 991-1010, 2015.

[7] V. Seymour, M. King, and R. Antonaci, "Understanding the impact of volunteering on proenvironmental behavioural change," Voluntary Sector Review, Review vol. 9, no. 1, pp. 73-88, 2018.

[8] G. M. T. Sloane and U. Pröbstl-Haider, "Motivation for environmental volunteering - A comparison between Austria and Great Britain," Journal of Outdoor Recreation and Tourism, Article vol. 25, pp. 158-168, 2019.

[9] R. H. Scott and E. van Etten, "Environmental and conservation volunteering as workplace integrated learning for university students," Issues in Educational Research, Article vol. 23, no. 2 SPL, pp. 242-257, 2013. 